\title{
Scott A. Shane: winner of the Global Award for Entrepreneurship Research
}

\author{
Per Davidsson · Johan Wiklund
}

Accepted: 1 March 2009/Published online: 9 June 2009

(C) Research Institute of Industrial Economics 2009

\begin{abstract}
Scott A. Shane is the 2009 winner of the Global Award for Entrepreneurship Research. In this article we discuss and analyze Shane's most important contributions to the field of entrepreneurship. His contribution is extraordinarily broad in scope, which makes it difficult to pinpoint one or a few specifics that we associate with Shane's scholarship. Instead, they can be summarized in the following three points. First, he has influenced what we view as central aspects of entrepreneurship. Shane has been a leading figure in redirecting the focus on entrepreneurship research itself. Second, he has influenced how we view entrepreneurship. Shane's research is arguably theory driven and it applies and develops theoretical lenses that greatly improve our understanding of entrepreneurship. Third, he has contributed to how we conduct entrepreneurship research. Shane has been a forerunner in examining relevant units of analysis that are difficult to sample; research designs and databases
\end{abstract}

\footnotetext{
P. Davidsson ( $\square)$

Queensland University of Technology, Brisbane, Australia

e-mail: per.davidsson@qut.edu.au

P. Davidsson · J. Wiklund

Jönköping International Business School,

Jönköping, Sweden

J. Wiklund

Syracuse University, Syracuse, New York, USA

e-mail: jwiklund@syr.edu
}

specifically designed for studying entrepreneurial processes; and sophisticated analytical methods. This has contributed to advancing the methodological rigor of the field. Summing them up, the contributions are very impressive indeed.

Keywords Entrepreneurship Award Winner · Theory development - Methodological development . Entrepreneurship

JEL Classifications $\quad$ G24 $\cdot$ L26 $\cdot$ M13 $\cdot$ O31

\section{Introduction}

Since 1996 the most prestigious award for outstanding research contributions to entrepreneurship has been the International Award for Entrepreneurship and Small Business Research, founded and administrated by the Swedish Foundation for Small Business Research (FSF) and the Swedish Agency for Economic and Regional Growth (NUTEK). In 2009 the price was upgraded and renamed the Global Award for Entrepreneurship Research, awarded by a new organization which now includes as well the Research Institute of Industrial Economics (IFN). New procedures for nomination, evaluation, and selection of award winners are more structured and transparent than ever, and the Prize amount is being 
roughly doubled to 100,000 Euros. ${ }^{1}$ The inaugural winner of the Global Award is Scott A. Shane. This article aims to summarize Shane's most important and vital contributions to the field of entrepreneurship.

While scholars for decades have agreed that entrepreneurship is an essential topic for social science, the entrepreneurship research field has nevertheless struggled with legitimacy issues. There are three common criticisms of the field of entrepreneurship research - its lack of agreement on the essential domain of the field, low methodological rigor, and a general failure to publish research in leading disciplinary or mainstream management outlets (Busenitz et al. 2003; Davidsson 2003). In all three areas, Shane has made substantial contributions, leading by example. He is guided by a clear view of entrepreneurship which has come to strongly influence scholarly work in this field, and he publishes rigorous work in the leading journals.

Shane is also an unusually "complete" entrepreneurship scholar in terms of having made empirical as well as conceptual and methodological contributions. He has published significant works regarding all major aspects or components of the entrepreneurship phenomenon - the individual[s]; the opportunity; the organizational context; the environment; and process issues - all of the above (usually) as related to various types of outcomes. He has also covered the entire spectrum from the majority of mundane, imitative start-ups to the "high end" of researchbased, technology-intensive and venture capitalbacked ventures, using data from several countries. In his work he has gained novel insights through the application of both qualitative and sophisticated quantitative techniques for data collection and analysis. It will be fruitful to describe and analyze Shane's specific contributions within relevant domains one at a time.

\section{The individual(s) in entrepreneurship}

While also investigating - and arguing for - the importance of diverse influences, Shane consistently emphasizes that entrepreneurship requires human

\footnotetext{
${ }^{1}$ The increased resources were made available through a generous donation from the Swedish entrepreneur Rune Andersson and his holding company Mellby Gård AB.
}

agency (e.g., Shane 2003). It is thus not surprising that several of his studies look into the characteristics of individual entrepreneurs. Shane's first contribution in this genre compares corporate venturing champions with non-champions (Shane 1994). In looking at internal champions rather than independent firm founders Shane introduced a novel perspective, and worked with richer data than most contemporaries in using data from over 4,000 individuals in 68 countries. The study found important differences between the two groups, and concluded that these were consistent across cultures.

House, Shane, and Herold (1996) is an early rebuttal of the critique by Gartner $(1988 ; 1989)$ and others of dispositional (trait) research in entrepreneurship. In a subsequent conceptual piece, Shane sides with Ed Locke in an additional call for reestablishing the role of individual dispositions with a specific focus on entrepreneurship (Shane et al. 2003).

Shane (2000a) - his single most influential, soleauthored work - exploited a unique research opportunity and is an example of an unusually clever and imaginative case study design. Shane uses interviews and archival data to document all the venture start-up attempts based on an advanced MIT technology, namely three-dimensional "printing" $\left(3 \mathrm{DP}^{\mathrm{TM}}\right)$. He examined how this single technology led to different types of innovations and ventures. Holding the technology constant, he avoids success bias as well as much unobserved heterogeneity across the cases. Using Austrian economics' ideas of private knowledge and a rich set of qualitative data, Shane convincingly demonstrates key insights regarding entrepreneurial opportunities: their non-obviousness (only eight start-up attempts based on a this widely publicized, broadly applicable, novel technology); the prevalence of non-search for the opportunities (cf. Kirzner 1973, regarding "alertness" and "surprise"); and the individual-opportunity nexus (cf. the next section). Regarding the latter, Shane argues that Team A could never have conceived of or succeeded with Opportunity B, and vice versa across all teamopportunity combinations. In each case the discovery and/or exploitation of the opportunity was clearly linked to some particular prior knowledge represented in the founding team.

There is a widespread consensus that this article has had a profound effect on the field, particularly on 
how researchers now recognize and think about the role of prior experience and how it influences preparedness for specific opportunities, rather than entrepreneurial action in general. The findings also accord with the view that entrepreneurial opportunities are in part inseparable from qualities of the individuals who pursue them (cf. Dimov 2004; McMullen and Shepherd 2006).

Recently, Shane has entered into the novel and controversial territory of the influence of genetic heritage on entrepreneurial behavior. Nicolaou and Shane (2008) outline the four mechanisms by which such effects might work. In Nicolaou et al. (2008) Shane teams up to conduct twin studies with researchers who have rich data and broad experience in this area. The analysis of large samples of monozygotic and dizygotic, same sex twins suggest a relatively strong effect of genetics on various measures of entrepreneurship when the core measure is self-employment. While novel and interesting, this work is all programmatic, containing substantial limitations admitted by the researchers. This line of research needs more investigation, and may represent an important lens through which we can improve our understanding of enterprising individuals.

\section{The entrepreneurial opportunity}

Shane and Venkataraman (2000) pointed out that relative to the concentration on the influence of characteristics of individuals (and environments), entrepreneurship researchers had severely neglected the characteristics of the entrepreneurial opportunities these individuals pursue. Although their view has received substantial following, their adoption of Casson's (1982) definition of opportunity has been criticized (Davidsson 2003; Singh 2001). Shane and Eckhardt (2003) heed such criticisms by making three explicit extensions: broadening, clarifying, and updating. In terms of clarifying, they offer an incisive re-formulation of the Cassonian definition of opportunity: "[T]hose situations in which new goods, services, raw materials and organizing methods can be introduced through the formation of new means, ends, or means-ends relationships" and argue that "These situations do not need to change the terms of economic exchange to be entrepreneurial opportunities, but only need to have the potential to alter the terms of economic exchange" (p. 165). In further response to criticism of being overly objectivist, they explain that "discovery" refers to perception of opportunity, and not proof that a "real" opportunity (as defined above) has been found.

In terms of broadening, the authors elaborate on the inadequacy of the price mechanism in relation to decisions involving new means-ends relationships (as opposed to optimization within known means-ends frameworks). They also mention several additional drivers behind discovery and exploitation of opportunities, beyond those already discussed by Shane and Venkataraman (2000). Another interesting extension is their discussion of modes of discovery and modes of exploitation (both in independent vs. corporate contexts). Crossing the two highlights four possibilities: a) fully independent start-ups; b) corporate acquisition of independent discoveries; c) spin-out of corporate discoveries, and d) corporate entrepreneurship. This simple framework regarding what types of opportunities are likely to be discovered and exploited in what type of context could be fertile ground for further theorizing and empirical work.

Further extensions of the theorizing on opportunities are offered in two chapters (2 and 3) of Shane (2003). Here the author seemingly takes another step in the subjective direction by defining opportunity as "a situation in which a person can create a new means-ends framework for recombining resources that the entrepreneur believes will yield a profit." In the discussion of Schumpeterian vs. Kirznerian opportunities he suggests that creation is involved in the former type (p. 21). This is a less objectivist position than he had previously held. However, here as in all his writings Shane maintains that opportunities have an external component (e.g., p. 42).

Shane's (and his collaborators) highlighting of the characteristics of opportunities has brought attention to and a clear focus on an essential dimension that was previously sorely under-researched relative to the role of characteristics of environments and individuals. However, while Shane's work has led to some progress and inspiration for others, considerable conceptual issues remain unresolved and further work is needed in this area. 


\section{Organizational context}

\subsection{Franchising}

Franchising was the topic of a number of Shane's articles in 1996-98 (e.g., Shane 1996b; 1996c; 1998). During this period he also made an explicit attempt to increase theoretical and empirical interest in this important form of venturing by co-organizing conferences and co-editing two special issues on the topic in the Journal of Business Venturing (Hoy and Shane 1998; Shane and Hoy 1996). He has recently returned to the area with publications in high prestige outlets (Mitsuhashi, Shane, and Sine 2008; Shane, Shankar, and Aravindakshan 2006).

In Shane (1996b) he abstracts from the particulars of franchising and positions its analysis in the broader context of hybrid organizations, i.e., the mix of market and hierarchy solutions. More specifically, he derives two broad hypotheses from agency theory: among franchisors, those who emphasize growth through franchising (rather than wholly owned outlets) will grow more and have better odds of survival. In his characteristic manner, he studies these phenomena with methodological sophistication, following a cohort of 138 new franchisors for 10 years from their inception in 1983. Both hypotheses are supported. In the theoretical discussion Shane notes that franchising as a hybrid organizational form largely overcomes Penrose's (1959) managerial capacity restriction on growth. He also explains why it is superior to profit sharing as a means for alignment of interests.

Shane (1998) uses a similar sample of 157 franchise systems established in 1981-83 to test nine hypotheses derived from agency theory. The overarching argument is that franchise systems that are structured to economize on agency costs are less likely to fail. With six of nine hypotheses empirically supported, Shane concludes agency concerns rather than resource constraints govern the behavior of franchisors.

In Shane (1996c) he combines his interests in franchising and international venturing. Again using agency theory as the vantage point, he hypothesizes that franchisors who have accumulated more monitoring capability, and who employ a fee arrangement with a larger bond element, will be more prone to expand internationally. Data from the 815 largest franchisors in the US are used for testing these two hypotheses and both are supported.

In Shane et al. (2006), he again demonstrates his ability to conceptually categorize a phenomenon as a special case of a more general phenomenon, thereby making it possible to benefit from theories and empirical findings regarding other manifestations of the general phenomenon. In this case it is the cooperative nature of franchising that is emphasized. Building on research in entrepreneurship, marketing, organization theory, strategic management, and finance, the authors develop nine linear and interactive effects hypotheses predicting the size of the franchise system. As usual, the research design and the quality of the empirical work are very sophisticated. Longitudinal data from close to 1,300 franchise systems established between 1979 and 1996 are used. Eight out of the nine hypotheses receive support. Finally, in a very recent article (Mitsuhashi et al. 2008) the authors challenge received "truths" based on cross-sectional evidence (which is often subject to survivor bias and time-specific idiosyncrasies). However, the spectrum of data and research questions of these studies largely places it outside of the entrepreneurship domain.

In sum, Shane has helped in a major way to bring franchising into the entrepreneurship research discourse. In doing so he has also provided the phenomenon with appropriate theoretical frames, and led by example in upgrading the quality of its empirical study.

\subsection{The venture capital relationship}

Like franchising, the entrepreneur-venture capitalist dyad can be regarded as a hybrid organizational form that is of particular interest to entrepreneurship scholars. Shane has co-authored a small number of influential (or potentially influential) high-quality articles on this topic as well. Cable and Shane (1997) is a conceptual paper published in the Academy of Management Review. At the time of publication, prior research on entrepreneur-venture capitalist relationships was typically either at worst atheoretical or at best employed an agency theory framework. As the authors note, "the agency perspective is actually a subset of the broader explanation of these relationships provided by the Prisoner's Dilemma approach" (pp. 146-147). Using this classic 
approach, the authors draw eclectically on various theoretical perspectives and prior results to develop a set of specific propositions regarding a) what influences the degree of cooperation in the entrepreneurVC relationship, and b) how these influences vary over the stages of the relationship. The influences are organized under the following headings: perceived time pressure, perceived payoff from cooperation, information, personal similarity, and transaction procedures (several of these include sub-categories). This article can be rated as a very welcome dissection of the main themes essential to the theoretical understanding of the complicated entrepreneur-VC relationship. The depth of insightful theorizing in this article is noteworthy.

A second article with Daniel Cable (Shane and Cable 2002) is primarily an example of good research craftsmanship. The authors argue that the usual economic explanations of how information asymmetries are dealt with between entrepreneurs and venture capitalists (allocation of contractual rights, staging of investments over time, and risk shifting) are under-socialized and incomplete because of a) entrepreneurs' over-optimism, and b) the incomplete possibilities of risk shifting for equity investors. The authors use a combination of qualitative (interviews with 50 seed-financed technology ventures) and quantitative data (survey of 220 seed-stage VCs and business angels). Despite its simplicity, the survey has an unusual and clever design element in that a random half of the sample is asked about a recent proposal they invested in, and the other random half is asked about a proposal they considered but turned down. One aspect of the results - mediation by the entrepreneur's prior (publicly known) reputation - leads to the requisite clarification of the precise theoretical mechanisms. According to the authors, this suggests that direct and indirect ties are valuable because they provide information - and that this rather than "social obligation" is what governs investment decisions.

By and large, Shane represents the conventional view that financial capital plays an important and positive role in entrepreneurial endeavors. However, he is certainly cognizant that only a tiny minority of new ventures ever obtain financing from business angels or venture capitalists (Shane 2008). Moreover, he is also the co-author of one article that forms part of what is still a small literature on how resource abundance - in particular as regards financial resources - can have exceedingly subtle detrimental effects (cf., e.g., Mosakowski 2002). Contrary to their hypothesis regarding availability of venture capital (which is only one of several factors they investigate), Katila and Shane (2005) do not find support that reaching first sales would be more likely, and giving up the license less likely, for technologylicensing firms operating in industries that are better provided with venture capital. The authors suggest three possible explanations for this finding, one of which is that venture capital and product sales are alternative ways to access capital. That is, success in attracting VC may reduce attention to the necessity of attracting and satisfying customers.

Shane's contribution to the literature on the entrepreneur-VC relationship is limited in volume but contains works of high originality which may well become influential in the field.

\section{The environment}

\subsection{International entrepreneurship}

International entrepreneurship was Shane's first area of research. Most of the entries under this heading deal with national differences as an environment issue. Several of the works focus on national cultural differences as defined and measured by Hofstede (1980). For example, Shane (1992) hypothesizes and finds that nations characterized by high individualism and low power distance will have higher invention rates per capita (as measured by patents). Shane (1993) is partly overlapping as it suggests that individualism and power distance have the same effects as suggested above on national innovation, measured as per capita trademarks. He here also adds hypotheses of a positive effect of masculinity and a negative effect of uncertainty avoidance. The results are as expected, except for failure to support the effect of "masculinity". Both of these studies use data from 33 countries.

McDougall, Shane, and Oviatt (1994) is one of two foundational articles in research on "international new ventures" (the other being Oviatt and McDougall 1994). The focus is on a new phenomenon - new ventures that go international at a very early stage. McDougall et al. (1994) demonstrate the inadequacy 
of received explanations of this phenomenon. Using theoretical analysis and qualitative data the authors stress the primary importance of the individual entrepreneur's knowledge and background. This article has been particularly fruitful for both theory development and triggering empirical research on a new and important phenomenon. For Shane, rather than deriving or for that matter fitting with his other work on national (cultural) differences and their effects, this work is best seen as a precursor to his work regarding the role of individuals' prior knowledge (Shane 2000a) and the "individual-opportunity nexus" (Shane and Eckhardt 2003; Shane and Venkataraman 2000).

Overall Shane in his early work on entrepreneurship and national environments ran well ahead of the crowd. He had a keen originality in the formulation of basic research questions, being more theory-driven and hypothesis-testing minded, and using larger/ better data sets, than what was normal at the time. For example, he advanced a more sophisticated (than the contemporary norm) use of control variables and testing of interaction effects, etc. On some occasions as a result he achieved publication in prestigious mainstream journals, which at the time was unusual for entrepreneurship research (Busenitz et al. 2003).

\subsection{Academic entrepreneurship}

Entrepreneurship in or out of a university setting can be understood as either an environment or an organizational context issue. Either way, this is another area where Shane (and collaborators) has made significant contributions. The book Academic Entrepreneurship: University Spinoffs and Wealth Creation (Shane 2004a) summarizes the work of Shane and others, and provides a very useful overview of research in this area.

Shane's own work using the patent level version of the longitudinal MIT data base reflects good craftsmanship and also led to original insights (Shane 2001a; 2001b; 2002). Via a good combination of theoretical and methodological "tools" these works yield some novel and non-obvious insights allowing the reader to ask and answer key questions: Under what circumstances is technology commercialization from universities more likely? What form is it more likely to take? What outcomes can be expected? Di Gregorio and Shane (2003) is another instance of this kind of creative work in more or less the same vein. Here, the intention is to explain why some universities generate more start-ups than others. It turns out that the suggested drivers - access to venture capital; relative emphasis on commercially-oriented research; intellectual eminence, and university policies (e.g., on equity holdings) successfully predict variance in commercialization efforts among elite universities, yet falls short of providing satisfactory explanation for the variance among "lesser" institutions. Quite possibly this reflects the causal ambiguity (King and Zeithaml 2001) that makes copying of apparent success recipes so difficult.

Two works focus on the effects of the Bayh-Dole Act, which intended to give universities stronger incentives to commercialize their research. At the time of the first of these works other researchers had concluded - somewhat counter-intuitively - that the Act was not responsible for the apparent increase in university commercialization efforts. While Shane (2004b) is careful to point out that his results do not necessarily contradict that aggregate conclusion, he shows that the Act appears to have influenced universities to focus more on technologies that lend themselves to licensing. Shane concludes that previous studies may have performed the analysis on too aggregated a level. In Shane and Somaya (2007) the authors conclude that the Bayh-Dole Act may have had unintended effects due to litigation issues, and that this may specifically have limited the spawning of new and small firms from university research.

\section{The entrepreneurial process}

Shane has made contributions to the study of the new venture creation process in a series of papers in collaboration with Frédéric Delmar and based on the Swedish counterpart study of the Panel Study of Entrepreneurial Dynamics (PSED; see Gartner, Shaver, Carter and Reynolds 2004; Reynolds 2007). In terms of an analytical approach this series of papers represent some of the most sophisticated based on this type of data. The PSED represents an empirical research approach that is likely to remain central to entrepreneurship studies. Therefore, this is an important contribution. First, the authors have pioneered the re-organization of the data set from a panel of four interview waves to a data set consisting 
of monthly spells, based on the answers to a number of time stamped (by year and month) "gestation activities" in the survey (cf. Reynolds 2007). This is very valuable methodologically because there is no avoiding the hard fact that when first captured some of the cases will be very early in the start-up process while others are close to completing it. The re-organization does not alleviate the issue but certainly facilitates controlling for it, allowing the application of Event History Analysis which makes more effective use of these panel data.

Substantively, Delmar and Shane (2003) theoretically argue - and find - that business planning activity reduces the risk of disbanding of the start-up, while having a positive effect on product development progress and the completion of other organizing activities. In a second, partly overlapping article, Delmar and Shane (2004) regard the development of a business plan as well as the establishment of a legal entity as "legitimating" behaviors that should be completed early in the process. They argue and find that these activities have a negative effect on disbanding and a positive effect on completing other gestation activities. In a third paper, again partly overlapping, Shane and Delmar (2004) argue specifically that planning activities should precede marketing activities in order for the start-up to avoid discontinuation.

Eckhardt, Shane and Delmar (2006) apply multistage selection modeling to the problem of predicting which new ventures receive external funding. Conventionally, such a research question would refer to some characteristics of the founders and some characteristics of the venture - and possibly some interaction between the two - in the same regression analysis. Logically, however, receiving external funding requires that the founders first actively seek such funding. Therefore, the multi-stage selection approach may be more valid than the alternative estimation of interaction effects. This approach also acknowledges the process nature of venture funding.

Accordingly, Eckhardt et al. (2006) hypothesize that in the first stage variables reflecting founders' subjective assessment of the future outlook for the venture determine whether external finance will be sought or not, and estimate these relationships. In a second stage they hypothesize (and estimate) that objectively verifiable characteristics of the venture will determine external investors' willingness to fund the venture, given that financing is sought. The results come out differently, but in their particular case not very markedly different from a model where in a single analysis external funding is regressed on both founder perceptions and venture characteristics. However, the analytical approach they use is potentially a very important tool for entrepreneurship because it speaks generally to the central fact that entrepreneurship requires human agency (Shane 2003). In many cases, other variables can have their effects but only if the entrepreneur chooses to let them. As a model for how to account for this the article by Eckhardt et al. (2006) arguably deserves more attention than it has so far received.

\section{Giving overall direction to entrepreneurship as a field of research}

Shane is co-author of the previously mentioned and extremely influential "conceptual framework" article "The promise of entrepreneurship as a field of research" (Shane and Venkataraman 2000; 2001). The central premise of this work is that "For a field of social science to have usefulness, it must have a conceptual framework that explains and predicts phenomena not explained or predicted by conceptual frameworks already in existence in other fields" (p. 217). The authors aim to provide such a framework, stating that the scholarly domain of entrepreneurship research entails "[T]he scholarly examination of how, by whom, and with what effects opportunities to create future goods and services are discovered, evaluated, and exploited (Venkataraman 1997). Consequently, the field involves the study of sources of opportunities; the processes of discovery, evaluation, and exploitation of opportunities; and the set of individuals who discover, evaluate, and exploit them" (p. 218). They further point out the following three sets of research questions as especially central: 1) why, when and how opportunities for the creation of goods and services come into existence; 2) why, when and how some people and not others discover and exploit these opportunities; and 3) why, when and how different modes of action are used to exploit entrepreneurial opportunities. In the subsequent dialogue they add that the outcomes - on different levels of analysis - of the exploitation process represent a 
fourth important set of research questions (Shane and Venkataraman 2001).

With regard to the antecedents of the process and its outcomes, they straightforwardly emphasize the characteristics of individuals and opportunities as the first-order forces explaining entrepreneurship, and hold environmental forces to be second order. They describe their perspective as a disequilibrium approach and highlight variations in the nature of opportunities as well as across individuals. Further, they point out that entrepreneurship does not require, but can include, the creation of new organizations. A short list of the many virtues in this way of delineating entrepreneurship research must include (cf. Davidsson 2003):

- It defines the scholarly domain rather than suggesting yet another definition of the societal phenomenon. Making this distinction is in itself a contribution.

- It focuses on the creation of future goods and services, thereby directing attention to the problem of emergence. This adds to entrepreneurship research an element that is largely missing in established theories in economics and management.

- While retaining a sound interest in individuals it helps to make entrepreneurship research less "one-legged" by giving equal status to characteristics of opportunities, and focusing on individuals' fit with the specific opportunity rather than general characteristics of entrepreneurs.

- It is sufficiently inclusive by considering both discovery and exploitation, and by not restricting the age, size or ownership of the organizations in which opportunities are pursued. At the same time it does not require purposefulness. It thereby makes room for luck and serendipity in entrepreneurial processes, and makes the existence of alternative modes of exploitation for given opportunities an important research issue.

- Yet, it is sufficiently restrictive by focusing on market related novelty rather than including organizational change per se, or creative behavior in any context. It thereby carves out a realistic domain of manageable scope with relatively clear boundaries which is consistent with Kirzner's (1973) ideal notion that entrepreneurship is what drives the market process.
After having defined the field and its central research questions, the remainder of the conceptual piece elaborates on the possible antecedents of existence, discovery and exploitation of opportunities as well as further highlighting the issue of different modes of exploitation. The result is a significant decoupling of entrepreneurship from the creation of new, independent firms (only).

Shane's sole-authored book A General Theory of Entrepreneurship: The Individual-Opportunity Nexus (Shane 2003) is used in doctoral training at many universities and is one of the most influential works in the field in recent years. In the book Shane elaborates and refines the reasoning around the themes in the above-mentioned article. He also provides a very comprehensive review of prior empirical research that is impressive in a number of ways. First, his encyclopaedic mastery of the literature is truly admirable, extending far outside of the realm of narrowly dedicated entrepreneurship journals. Second, for a US-based author, he shows an unusual awareness of and willingness to cite research conducted in a broad range of countries. Third, the review recognizes the role of quality, meaning that he leans more heavily on theory-driven and comprehensive studies. At the same time, there is a clash between Shane's perspective on entrepreneurship and the empirical evidence he reviews. As described above, his notion of entrepreneurship emphasizes the interacting explanations for the processes of emergence of new and (at least to some extent) innovative economic activity, regardless of organizational or ownership context. In sharp contrast, most of the research he cites employs little of such a process view; generally assumes additive effects rather than interactions, and uses the status of self-employment or the entry of new independent businesses innovative as well as imitative, but with the latter a marked majority - as the operational criterion of entrepreneurship. While this incompatibility may make the empirical evidence less convincing as support for his theoretical propositions, it also points out the need for more empirical research taking the views developed by Shane and Venkataraman (2000) and Shane (2003) as the vantage point. We would argue that thanks to these contributions, the volume of such work has dramatically increased in recent years. 
The background already sketched allows us to appreciate how his recent monograph The Illusions of Entrepreneurship: The Costly Myths that Entrepreneurs, Investors, and Policy Makers Live by (Shane 2008), while in its "packaging" less scholarly than usual, steadfastly aims at getting some basic bearings on the phenomenon right and should help shape the overall direction of the field. Shane's trailblazing work is evident in his editorship of a comprehensive compilation of foundational works (Shane 2000b); of the entrepreneurship department of Management Science as well as of special issues of other journals, and his giving a one-week doctoral seminar twice a year for participants from around the globe.

\section{Conclusions}

As has been demonstrated, Shane's contribution is extraordinarily broad in scope. This is particularly impressive because he is only in mid-career, his first article having appeared less than two decades ago. It also suggests that he has extraordinary curiosity and hunger for knowledge - essential preconditions for successful scholarship.

It is the very breadth of his contribution that we have taken into consideration that makes it difficult to pinpoint one or a few specific findings that we associate with Shane's scholarship. Therefore, we believe that it is fruitful to summarize Shane's contribution to entrepreneurship research as follows. First, Shane has been a central figure in redirecting the focus on entrepreneurship research, influencing what we view as its central aspects. Second, he has influenced how we view entrepreneurship. Shane's research is arguably theory driven and it applies and develops theoretical lenses that help us better understand entrepreneurship Third, he has contributed to how we conduct entrepreneurship research. Shane has been a forerunner in examining relevant units of analysis that are difficult to sample; research designs and databases specifically designed for studying entrepreneurial processes, and sophisticated analytical methods. All of this has contributed to advancing the methodological standard of the field. Summing them up, the contributions are very impressive indeed.

\section{References}

Busenitz, L., West, G. P. III, Shepherd, D., Nelson, T., Chandler, G. N., \& Zacharakis, A. (2003). Entrepreneurship research in emergence: Past trends and future directions. Journal of Management, 29(3), 285-308.

Cable, D. M., \& Shane, S. (1997). A prisoner's dilemma approach to entrepreneur-venture capitalist relationships. Academy of Management Review, 22(1), 142-176.

Casson, M. (1982). The entrepreneur. Totowa, NJ: Barnes \& Noble Books.

Davidsson, P. (2003). The domain of entrepreneurship research: Some suggestions. In J. Katz \& D. Shepherd (Eds.), Cognitive approaches to entrepreneurship research (Vol. 6, pp. 315-372). Oxford, UK: Elsevier/JAI Press.

Delmar, F., \& Shane, S. (2003). Does business planning facilitate the development of new ventures? Strategic Management Journal, 24(12), 1165-1185.

Delmar, F., \& Shane, S. (2004). Legitimating first: Organizing activities and the survival of new ventures. Journal of Business Venturing, 19(3), 385-410.

Di Gregorio, D., \& Shane, S. (2003). Why do some universities generate more start-ups than others. Research Policy, 32(2), 209-227.

Dimov, D. P. (2004). The individuality of opportunity recognition: A critical review and extension. In J. E. Butler (Ed.), Opportunity identification and entrepreneurial behavior (pp. 135-162). Greenwich, CT: IAP.

Eckhardt, J., \& Shane, S. (2003). Opportunities and entrepreneurship. Journal of Management, 29(3), 333-349.

Eckhardt, J., Shane, S., \& Delmar, F. (2006). Multistage selection and the financing of new ventures. Management Science, 52(2), 220-232.

Gartner, W. B. (1988). "Who is an entrepreneur?" is the wrong question. American Small Business Journal, 12(4), 11-31.

Gartner, W. B. (1989). Some suggestions for research on entrepreneurial traits and characteristics. Entrepreneurship Theory and Practice, 13(4), 27-37.

Gartner, W. B., Shaver, K. G., Carter, N. M., \& Reynolds, P. D. (2004). Handbook of entrepreneurial dynamics: The process of business creation. Thousand Oaks, CA: Sage.

Hofstede, G. (1980). Culture's consequences: International differences in work-related values. Beverly Hills, CA: Sage Publications.

House, F. T., Shane, S., \& Herold, D. M. (1996). Rumors of the death of dispositional research are vastly exaggerated. Academy of Management Review, 21(1), 203-224.

Hoy, F., \& Shane, S. (1998). Franchising as an entrepreneurial venture form. Journal of Business Venturing, 13(2), 9194.

Katila, R., \& Shane, S. (2005). When does lack of resources make new firms innovative? Academy of Management Journal, 48(5), 814-829.

King, A., \& Zeithaml, C. (2001). Competencies and firm performance: Examining the causal ambiguity paradox. Strategic Management Journal, 22(1), 75-99.

Kirzner, I. M. (1973). Competition and entrepreneurship. Chicago, IL: University of Chicago Press. 
McDougall, P. P., Shane, S., \& Oviatt, B. M. (1994). Explaining the formation of international new ventures: The limits of theories from international business research. Journal of Business Venturing, 9(5), 469-487.

McMullen, J., \& Shepherd, D. (2006). Entrepreneurial action and the role of uncertainty in the theory of the entrepreneur. Academy of Management Review, 31(1), 132-152.

Mitsuhashi, H., Shane, S., \& Sine, W. D. (2008). Organization governance form in franchising: Efficient contracting or organizational momentum? Strategic Management Journal, 29(10), 1127-1136.

Mosakowski, E. (2002). Overcoming resource disadvantages in entrepreneurial firms: When less is more. In M. A. Hitt, R. D. Ireland, S. M. Camp, \& D. L. Sexton (Eds.), Strategic Entrepreneurship: Creating a New Mindset (pp. 106-126). Oxford, UK: Blackwell.

Nicolaou, N., \& Shane, S. (2008). Can genetic factors influence the likelihood of engaging in entrepreneurial activitiy. Journal of Business Venturing, doi:10.1016/j.busvent.2007. 11.003 .

Nicolaou, N., Shane, S., Cherkas, L., Hunkin, J., \& Spector, T. D. (2008). Is the tendency to engage in entrepreneurship genetic? Management Science, 54(1), 167-179.

Oviatt, B. M., \& McDougall, P. P. (1994). Toward a theory of international new ventures. Journal of International Business Studies, 25(1), 45-64.

Penrose, E. (1959). The Theory of the growth of the firm. Oxford: Oxford University Press.

Reynolds, P. D. (2007). New firm creation in the US: A PSED overview. Foundations and Trends in Entrepreneurship, $3(1), 1-151$.

Shane, S. (1992). Why do some societies invent more than others? Journal of Business Venturing, 7(1), 29-46.

Shane, S. (1993). Cultural influences on national rates of innovation. Journal of Business Venturing, 8(1), 59-73.

Shane, S. (1994). Are champions different from non-champions? Journal of Business Venturing, 9(5), 397-421.

Shane, S. (1996a). Explaining variation in rates of entrepreneurship in the United States: 1899-1988. Journal of Management, 22(5), 747-781.

Shane, S. (1996b). Hybrid organizational arrangements and their implications for firm growth and survival: A study of new franchisors. Academy of Management Journal, 39(1), 216-234.

Shane, S. (1996c). Why franchise companies expand overseas. Journal of Business Venturing, 11(2), 73-88.

Shane, S. (1998). Making new franchise systems work. Strategic Management Journal, 19(7), 697-707.

Shane, S. (2000a). Prior knowledge and the discovery of entrepreneurial opportunities. Organization Science, 11(4), 448-469.

Shane, S. (Ed.). (2000b). The foundations of entrepreneurship. Cheltenham: Edward Elgar.

Shane, S. (2001a). Technological opportunities and new firm creation. Management Science, 47(2), 205-220.

Shane, S. (2001b). Technology regimes and new firm formation. Management Science, 47(9), 1173-1190.

Shane, S. (2002). Selling university technology: Patterns from MIT. Management Science, 48(1), 122-137.

Shane, S. (2003). A general theory of entrepreneurship: The individual-opportunity nexus. Cheltenham, UK: Edward Elgar.
Shane, S. (2004a). Academic entrepreneurship: University spinoffs and wealth creation. Cheltenham, UK and Northampton, MA: Elgar.

Shane, S. (2004b). Encouraging university entrepreneurship? The effect of the Bayh-Dole Act on university patenting in the United States. Journal of Business Venturing, 19(2), 127-151.

Shane, S. (2008). The illusions of entrepreneurship: The costly myths that entrepreneurs, investors, and policy makers live by. New Haven, CT and London: Yale University Press.

Shane, S., \& Cable, D. M. (2002). Network ties, reputation, and the financing of new ventures. Management Science, 48(3), 364-381.

Shane, S., \& Delmar, F. (2004). Planning for the market: Business planning before marketing and the continuation of organizing efforts. Journal of Business Venturing, 19(6), 767-785.

Shane, S., \& Eckhardt, J. (2003). The individual-opportunity nexus. In Z. J. Acs \& D. B. Audretsch (Eds.), Handbook of entrepreneurship research (pp. 161-194). Dordrecht, NL: Kluwer.

Shane, S., \& Hoy, F. (1996). Franchising: A gateway to cooperative entrepreneurship. Journal of Business Venturing, 11(5), 325-327.

Shane, S., \& Khurana, R. (2003). Bringing individuals back in: The effects of career experience on new firm founding. Industrial and Corporate Change, 12(3), 519-543.

Shane, S., Kolvereid, L., \& Westhead, P. (1991). An exploratory examination of reasons leading to new firm formation across country and gender. Journal of Business Venturing, 6(6), 431-446.

Shane, S., Locke, E. A., \& Collins, C. J. (2003). Entrepreneurial motivation. Human Resource Management Review, 13(2), 257-279.

Shane, S., Shankar, V., \& Aravindakshan, A. (2006). The effects of new franchisor partnering strategies on franchise system size. Management Science, 52(5), 773-787.

Shane, S., \& Somaya, D. (2007). The effects of patent litigation on university licensing efforts. Journal of Economic Behavior and Organization, 63(4), 739-755.

Shane, S., \& Stuart, T. (2002). Organizational endowments and the performance of university start-ups. Management Science, 48(1), 154-170.

Shane, S., \& Venkataraman, S. (2000). The promise of entrepreneurship as a field of research. Academy of Management Review, 25(1), 217-226.

Shane, S., \& Venkataraman, S. (2001). Entrepreneurship as a field of research: A response to Zahra and Dess, Singh, and Erikson. Academy of Management Review, 26(1), 13-16.

Singh, R. P. (2001). A comment on developing the field of entrepreneurship through the study of opportunity recognition and exploitation. Academy of Management Review, 26(1), 10-12.

Venkataraman, S. (1997). The distinctive domain of entrepreneurship research: An editor's perspective. In J. Katz \& J. Brockhaus (Eds.), Advances in entrepreneurship, firm emergence, and growth (Vol. 3, pp. 119-138). Greenwich, CT: JAI Press. 